\title{
Productive Potential and Economic Viability of Soybeans in Response to Potassium Application
}

\author{
Marina Silveira Batista \\ Universidade Federal do Piauí - UFPI. Campus Professora Cinobelina Elvas, Bom Jesus - PI, \\ Brazil. E-mail: marina_silveira21@yahoo.com.br \\ Antônio Veimar da Silva (Corresponding Author) \\ Universidade Federal da Paraíba - UFPB, Campus Areia, Areia - PB, Brazil. \\ E-mail: veimar26@hotmail.com
}

Rosilene de Morais da Silva, Lariza Lustosa de Oliveira

Universidade Federal do Piauí - UFPI. Campus Professora Cinobelina Elvas, Bom Jesus - PI, Brazil. E-mail: rosilenemorais7@hotmail.com, lalalustosa200@ hotmail.com

Carla Michelle da Silva

Universidade Federal de Viçosa - UFV. Campus Universitário, Viçosa - MG, Brazil. E-mail: carla.mic@hotmail.com

\section{Fabio Mielezrski}

Universidade Federal da Paraíba - UFPB, Campus Areia, Areia - PB, Brazil. E-mail: mfabioagro@gmail.com

Received: Dec. 8, 2019

doi:10.5296/jas.v8i3.16558
Accepted: Feb. 20, $2020 \quad$ Published: Feb. 27, 2020

URL: https://doi.org/10.5296/jas.v8i3.16558

\begin{abstract}
The objective of this study was to find the best potassium dose to increase soybean yield, taking into account the economic viability of the crop in the studied region. Sixteen treatments of the interaction between potassium doses $\left(0,50,100\right.$ and $\left.150 \mathrm{~kg} \mathrm{ha}^{-1}\right)$ and application times (sowing, vegetative stage (V3), vegetative stage V3 + reproductive stage
\end{abstract}


(R1) and reproductive stage). The experiment was set up in a randomized complete block design with four replications. Plant growth and production characteristics were analyzed and a preliminary analysis of variance was applied to check the significance of the interactions for each characteristic by Tukey's test $(\alpha=0.05)$. Subsequently, the regression analysis was performed using SAS software (2013). The economic analysis was made using the Monte Carlo methodology (Lima, 2008), and processed with the software @Risk 7 (PALISADE, 2016). Potassium fertilization was positive with increase in yield, but there was no direct relation with the application period. The $109 \mathrm{KCl} \mathrm{ha}^{-1}$ dose provided greater economic viability in soybean cultivation.

Keywords: Glycine max, yield components, nutrients, productivity

\section{Introduction}

Soybean (Glycine max L. Merrill) is one of the most cultivated crops in the world and is highly important for the Brazilian agribusiness with prospects for increased production. Such perspective is due to the large extension of arable land in the Cerrado, especially in the North and Northeast regions of the country (GAVIOLI, 2012).

In the Northeast region is the Cerrado of the State of Piauí that constitutes the MATOPIBA (States of Maranhão, Tocantins, Piauí and Bahia) and has stood out in the Brazilian scenario due to its flat topography, deep soils and favorable climate for the cultivation of major crops of grains and fibers (BORGHI et al., 2014), which allowed agricultural expansion in this region.

Increased production is also directly related to proper plant nutrition and fertilizer management (OOSTERHUIS et al., 2014). Essential nutrients for soybean include potassium (K), which plays a particularly key role in plant production and vital physiological processes (HAO et al., 2015), such as growth and development, water relations, photosynthesis and enzymatic activity (MEENAA et al., 2014; PETTIGREW, 2008).

$\mathrm{K}$ availability depends on soil type and its physicochemical properties (ZÖRBA et al., 2014). Inadequate management of $\mathrm{K}$ can directly affect plant performance (SRINIVASARAO et al., 2016), as stomatal opening and closing becomes slower, which implies a more pronounced result of water deficit (SERAFIM et al., 2012). Thus, it causes inhibition of soybean plant photosynthesis, slower plant growth, poorly developed roots, lighter seeds and reduced yield (WANG, 2015).

There are recommendations of economically and environmentally appropriate doses for crops and soil classes, however, soybean response to $\mathrm{K}$ application is still divergent in the Cerrado region (PETTER et al., 2014), because nutrients have different responses in soil and according to plant mobility, influenced by the dose and time of application of the supplied nutrients (MARTINS et al., 2014).

To make the best decision, the producer needs to know the cost of production, especially related to fertilization, observing the optimal dose and timing of nutrient application. This is because the dose that gives the best result will not always be the dose that will result in the 
greatest economic return. Therefore, we have to be sure that the decision to be made is the one that requires less effort, fewer resources and guarantees the best result (RICHETTI, 2015).

There is still little research involving the productive potential and economic viability of soybean in the Cerrado of the State of Piauí. In this context, the goal of this study was to analyze the management of doses and times of application of potassium and the economic viability of soybean crop in the study region.

\section{Material and Methods}

The experiment was conducted in the 2016/2017 growing season, in the experimental area of São João do Pirajá Farm, State of Piauí, Brazil (9³'25.69'S and 44³3'12.89'W, and 570 m altitude).

Monthly climate data from the station located on the farm were collected, referring to the Average maximum and minimum temperature $\left({ }^{\circ} \mathrm{C}\right)$, rainfall $(\mathrm{mm})$ and insolation $(\mathrm{h})$ during the experiment period (Figure 1).

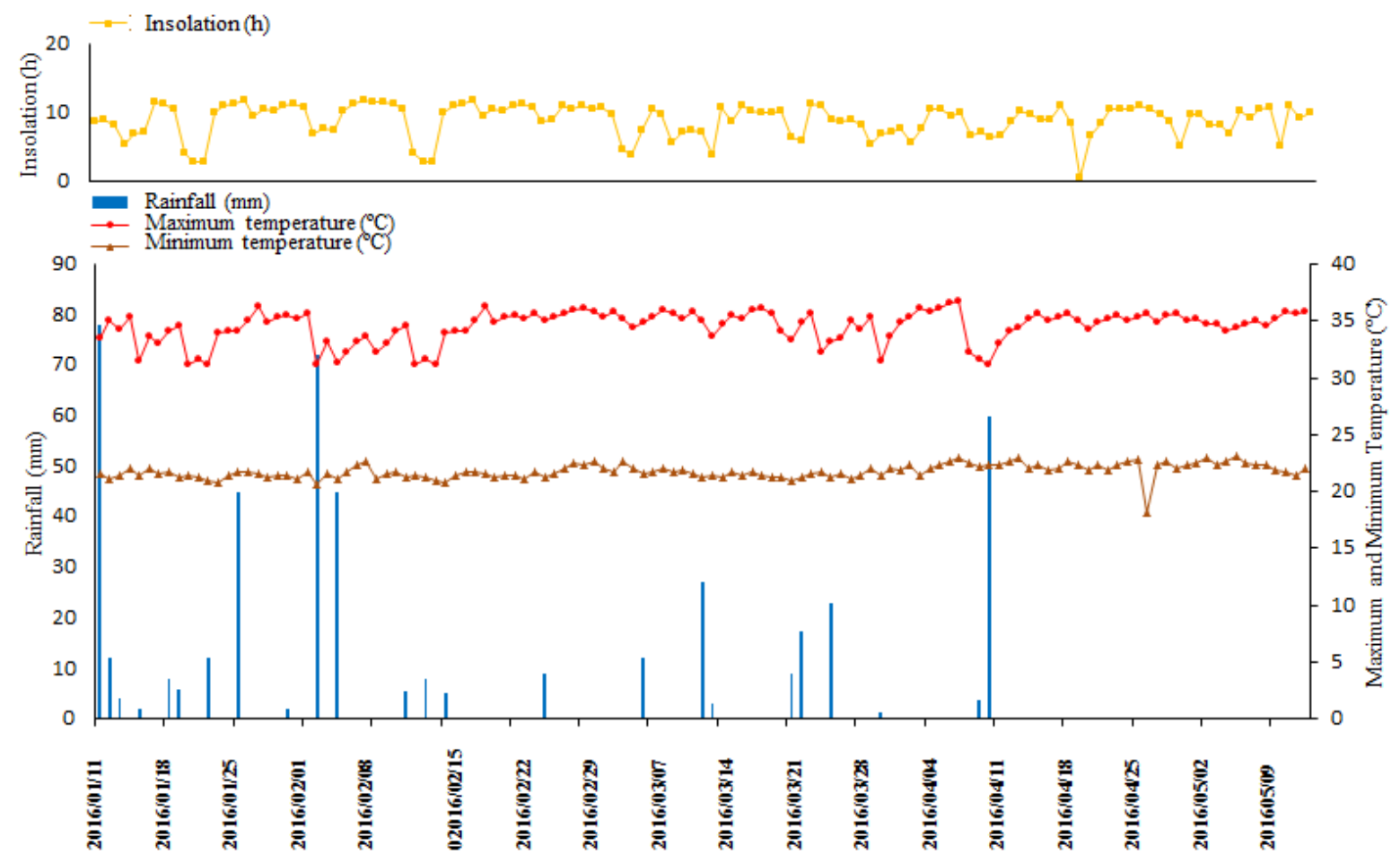

Figure 1. Average maximum and minimum temperature, rainfall and precipitation in the months of January to May 2016

The soil of the experimental area is classified as Yellow Latosol, with sandy loam texture (PRAGANA, 2011), with particle size distribution: total sand $=800 \mathrm{~g} \mathrm{~kg}^{-1}$; silt $=60 \mathrm{~g} \mathrm{~kg}^{-1}$; clay $=140 \mathrm{~g} \mathrm{~kg}^{-1}$, at a depth of $0.00-0.20 \mathrm{~m}$. The analysis regarding the chemical properties and the obtained concentrations were $\mathrm{OM}=15.93 \mathrm{~g} \mathrm{dm}^{-3} ; \mathrm{pH} \mathrm{CaCl} 2=4.8 ; \mathrm{P}=10.8 \mathrm{mg} \mathrm{dm}^{-3}$; $\mathrm{K}=0.07 \mathrm{cmol} \mathrm{dm}^{-3} ; \mathrm{Ca}=2.05 \mathrm{cmol} \mathrm{dm}^{-3} ; \mathrm{t}=0.37 \mathrm{cmol} \mathrm{dm}^{-3} ; \mathrm{Al}=0.0 \mathrm{cmol} \mathrm{dm}^{-3} ; \mathrm{H}+\mathrm{Al}=$ $2.16 \mathrm{cmol} \mathrm{dm}^{-3} ; \mathrm{SB}=2.49 \mathrm{cmol} \mathrm{dm}^{-3} ; \mathrm{CEC}=4.65 \mathrm{cmol} \mathrm{dm}^{-3} ; \mathrm{V}=53.5 \% ; \mathrm{m}=0.0 \%$. 
The soybean cultivar used was characterized as genotype 1, transgenic, determinate growth habit, maturity group 9.3, glyphosate-tolerant, with high yield and production stability.

Seeds were inoculated and treated with the following products: 4 doses of inoculant $5 \times 10^{9}$ colloid forming units (CFU) $\mathrm{mL} \mathrm{ha}^{-1}+140 \mathrm{~mL} \mathrm{ha}^{-1}$ Fipronil, Thiophanate Methyl and Pyraclostrobin; 1 dose of Bradyrhizobium elkanii strain 5019, 1 dose of Bradyrhizobium japonicum strain 5079; 1 dose of Bradyrhizobium japonicum $1 \times 10^{8}$ cell; and 1 dose of Bradyrhizobium japonicum semia $1 \times 10^{9}$ to obtain good root nodulation and to protect the seed during germination.

The experiment was set up in a $4 \times 4$ randomized complete block design with four replications. The first factor consisted of $0,50,100$ and $150 \mathrm{~kg} \mathrm{ha}^{-1}$ potassium doses and the second, of four application times: at sowing, vegetative stage (V3), vegetative stage $\mathrm{V} 3$ + reproductive stage (R1) and reproductive stage. (R1) (Table 1) using potassium chloride $(\mathrm{KCl})$ as a source. Each experimental plot consisted of ten rows, five meters long and 0.5 meters apart.

Table 1. Soil composition for each treatment, with different potassium doses at different application times

\begin{tabular}{|c|c|c|c|c|c|c|c|c|}
\hline \multirow{2}{*}{ Treatments } & \multirow{2}{*}{$\begin{array}{l}\mathrm{pH} \\
\mathrm{CaCl}\end{array}$} & $\begin{array}{l}\text { Phosph } \\
\text { orus }\end{array}$ & $\mathbf{K}$ & $\mathbf{C a}$ & Mg & Al & \multirow[t]{2}{*}{$\mathbf{H}+\mathbf{A l}$} & \multirow[t]{2}{*}{ SB } \\
\hline & & $\begin{array}{l}\mathrm{Mg} \\
\mathrm{dm}^{3}\end{array}$ & ---- & 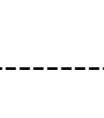 & $\mathrm{cmol}$ & & & \\
\hline Okg KCL control & 4.8 & 10.80 & 0.07 & 2.05 & 0.37 & 0.00 & 2.16 & 2.49 \\
\hline 50kg KCL R1 & 4.9 & 5.40 & 0.09 & 1.84 & 0.34 & 0.00 & 1.77 & 2.27 \\
\hline 50kg KCL V3 + R1 & 4.8 & 7.20 & 0.08 & 1.82 & 0.32 & 0.00 & 1.87 & 2.22 \\
\hline $50 \mathrm{~kg} \mathrm{KCL} \mathrm{V3}$ & 5.6 & 6.10 & 0.08 & 2.71 & 0.44 & 0.00 & 1.31 & 3.23 \\
\hline 50kg KCL sowing & 4.9 & 3.70 & 0.07 & 2.49 & 0.29 & 0.00 & 1.67 & 2.85 \\
\hline 100kg KCL R1 & 5.0 & 4.80 & 0.11 & 1.95 & 0.27 & 0.00 & 1.37 & 2.33 \\
\hline 100kg KCL V3 + R1 & 4.7 & 14.20 & 0.11 & 1.65 & 0.29 & 0.00 & 1.87 & 2.05 \\
\hline $100 \mathrm{~kg} \mathrm{KCL} \mathrm{V3}$ & 4.9 & 6.00 & 0.09 & 1.83 & 0.29 & 0.00 & 1.43 & 2.21 \\
\hline $100 \mathrm{~kg}$ KCL sowing & 5.1 & 5.20 & 0.11 & 2.05 & 0.40 & 0.00 & 1.02 & 2.56 \\
\hline 150kg KCL R1 & 4.7 & 6.00 & 0.12 & 1.91 & 0.32 & 0.00 & 2.36 & 2.35 \\
\hline
\end{tabular}




\begin{tabular}{|c|c|c|c|c|c|c|c|c|}
\hline 150kg KCL V3 + R1 & 4.9 & 7.90 & 0.15 & 2.29 & 0.34 & 0.00 & 2.24 & 2.78 \\
\hline $150 \mathrm{~kg} \mathrm{KCL} \mathrm{V3}$ & 4.4 & 6.70 & 0.14 & 1.21 & 0.28 & 0.10 & 2.52 & 1.63 \\
\hline $150 \mathrm{~kg}$ KCL sowing & 4.9 & 4.90 & 0.09 & 1.71 & 0.29 & 0.00 & 1.74 & 2.09 \\
\hline CEC & $\mathbf{V}$ & $\mathbf{m}$ & $\mathbf{O M}$ & Clay & Sand & Silt & \multirow{2}{*}{ Texture } & \\
\hline $\mathrm{cmol} \mathrm{dm}{ }^{3}$ & $\%$ & 0.00 & $\mathrm{~g} \mathrm{dm}^{3}$ & $-----\cdot$ & $\mathrm{g} \mathrm{Kg}^{-1}$ & ----- & & \\
\hline 4.65 & 53.5 & 0.00 & 15.93 & 140 & 800 & 60 & Sandy & \\
\hline 4.04 & 56.2 & 0.00 & 13.26 & 170 & 770 & 60 & Medium & \\
\hline 4.09 & 54.3 & 0.00 & 15.38 & 170 & 770 & 60 & Medium & \\
\hline 4.54 & 71.1 & 0.00 & 13.41 & 140 & 770 & 90 & Sandy & \\
\hline 4.52 & 63.1 & 0.00 & 11.93 & 170 & 770 & 60 & Medium & \\
\hline 3.70 & 63.0 & 0.00 & 12.59 & 140 & 770 & 90 & Sandy & \\
\hline 3.92 & 52.3 & 0.00 & 12.22 & 170 & 770 & 60 & Medium & \\
\hline 3.64 & 60.8 & 0.00 & 11.64 & 190 & 750 & 60 & Medium & \\
\hline 3.58 & 71.5 & 0.00 & 13.41 & 170 & 770 & 60 & Medium & \\
\hline 4.70 & 49.9 & 0.00 & 14.39 & 190 & 750 & 60 & Medium & \\
\hline 5.02 & 55.4 & 0.00 & 15.30 & 170 & 770 & 60 & Medium & \\
\hline 4.15 & 39.3 & 5.77 & 12.66 & 170 & 770 & 60 & Medium & \\
\hline 3.82 & 54.6 & 0.00 & 12.66 & 140 & 770 & 90 & Sandy & \\
\hline
\end{tabular}

Source: Research data, 2015/2016 agricultural year.

Sowing was held on January 6, 2016. Twenty-five seeds were deposited per linear meter and thinning was made when $80 \%$ plants reached the phenological stage V3, that is, when they presented two trifoliolate leaves. After thinning, there were 16 plants $/ \mathrm{m}$, making a final population of 330,000 plants $\mathrm{ha}^{-1}$. 
Growth data were evaluated at the end of the experiment, in which five soybean plants were randomly selected and marked in the useful area of the plot by repetition, where the following analyses were performed: Plant height: measured with a measuring tape, from the base of the plant's to the end of the main stem in $\mathrm{cm}$ (BOHN et al., 2016); Number of nodes, number of branches and number of trifoliate leaves: done manually (SOUZA et al., 2013).

After reaching physiological maturity and drying naturally, when the plants reached the R9 phenological stage, the grains were harvested. The collected pods were stored in plastic bags and taken to the Phytotechnics laboratory of the Federal University of Piauí (UFPI/CPCE), and threshed. Yield components comprise the following evaluated parameters: Number of pods per plant (NVP) - obtained by the ratio of the total number of pods to the total number of plants collected (Dalchiavon and Carvalho, 2012); Number of beans per pod (NGV) determined by the average number of seeds divided by the average number of pods from plants in the useful area of the plot (Dalchiavon and Carvalho, 2012); Pod length (CV) obtained by averaging the length of thirty pods from plants in the useful area of the plot with a digital caliper (1 mm) (SOUZA et al., 2013); Number of Pods in the Upper Third (NVTS) obtained by counting the number of pods in the upper third of the plant in a sample of 5 plants per plot. The result is expressed as number of pods in the upper third per plant (SCHMID et al., 2016); Number of Pods in the Middle Third (NVTM) and Number of Pods in the Lower Third (NVTI) - obtained by counting the number of pods in the middle and lower thirds in a sample of 5 plants per plot. The result is expressed in number of pods in the middle and lower thirds (SALES et al., 2016); One-thousand grain weight (PMG) - eight repetitions of 100 random grains were separated to be weighed, with the same decimal number, then the criteria described in Brasil (2009) were applied; and Yield (PROD) - the grains in the useful area of the plot were threshed and weighed on a decimal scale. The average yield of plants in the plot was calculated and transformed to $\mathrm{kg} \mathrm{ha}^{-1}$ (13\% moisture content on a wet basis) (BARBOSA et al., 2014).

In order to meet the assumptions of the analysis of variance, the number of pods in the middle third was transformed into logarithm base $10(\log 10)$. Statistical analyses were performed using the GLM (General Linear Model) and CORR (Correlation) procedures contained in the SAS - Statistical Analysis Systems (University Edition). Significances were declared at 5\% and $1 \%(\mathrm{P}=0.05$ and $\mathrm{P}=0.01)$ by the F-test.

The economic analysis was performed using Monte Carlo methodology (PAZZINI et al., 2014), with data simulation, considering a normal distribution of residues with adoption of 10,000 samples or iterations per treatment.

Subsequently, the statistical differences for $\mathrm{K}$ doses were tested and regression analysis was performed to obtain the production function, whose adjustment model was a third order polynomial. The calculations defined for this analysis follow the models prescribed by Theory of the Firm (CAMARGOS, 2008).

After obtaining the regression function, considering the standard error, normality was adjusted. From the polynomial function, to set the limits of rational use of $\mathrm{KCl}$ doses. Taking 


\section{Al Macrothink Institute $^{\mathrm{TM}}$}

into consideration the purchase values of the products equivalent to January 2017, the bag

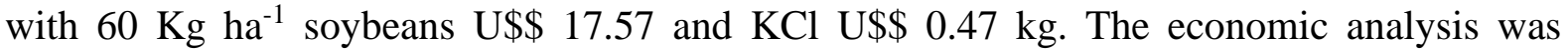
processed with the aid of @ Risk 7 software (PALISADE, 2016).

\section{Results and Discussion}

For the growth traits of soybean, there was no statistical significance for the dose $\mathrm{x}$ application time interaction. Considering the factors separately, dose and application time, only the plant height was significantly different between different doses and application times. The other variables had no statistical difference (Table 2).

Table 2. Summary of the analysis of variance for plant height (AP), number of leaves (NF), number of nodes (NN), and number of branches (NR)

\begin{tabular}{|c|c|c|c|c|c|}
\hline \multirow{2}{*}{ SV } & \multirow{2}{*}{$\mathrm{DF}$} & \multicolumn{4}{|c|}{ Mean square } \\
\hline & & AP & $\mathrm{NF}$ & NN & NR \\
\hline Dose & 3 & $21.66^{*}$ & 17.52 & 12.96 & 0.98 \\
\hline Time & 3 & $24.01 *$ & 17.17 & 8.83 & 1.9 \\
\hline Dose $\mathrm{x}$ time & 9 & 2.13 & 6.53 & 7.67 & 0.69 \\
\hline Error & 45 & 7.74 & 12.84 & 13.83 & 0.64 \\
\hline C.V. (\%) & & 9.25 & 18.45 & 18.55 & 27.82 \\
\hline
\end{tabular}

* Significant by F-test $(\mathrm{P}<0.05)$.

Both dose and time of application influence the plant height. This was observed in the regression (Figure 2), where the highest plant height was found at $59.75 \mathrm{~kg} \mathrm{ha}^{-1} \mathrm{KCl}$. The use of potassium at the optimal dose is essential for soybean cultivation, as it is related to several positive factors of the plant such as increased osmotic function, enzymatic activator, with participation in protein metabolism, photosynthesis, assimilate transport and cellular water potential (TAIZ and ZEIGER, 2013). In addition, weeds, grain yield and harvest losses can be controlled by taking into account mechanized operations. 


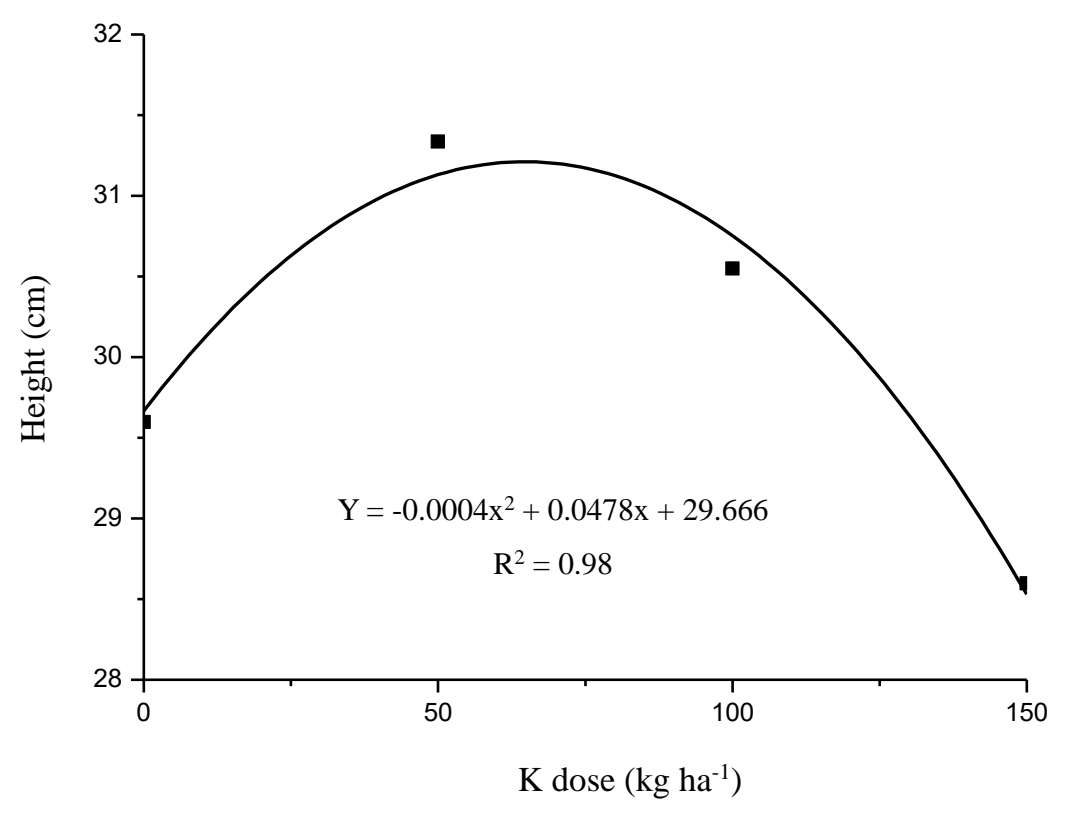

Figure 2. Height of soybean plants according to $\mathrm{K}$ doses

After the optimal dose, the height of the plant begins to decrease, this is because the excess of one nutrient reduces the effectiveness of others (law of the maximum), which in this case provides a nutritional imbalance with the gradual increase of $\mathrm{K}$ decreasing and affecting the effectiveness of $\mathrm{Ca}$ and $\mathrm{Mg}$. This is because they act directly on the cell wall structure and chlorophyll, respectively, because absorption of high amounts of $\mathrm{K}$ may reduce the uptake or physiological availability of Ca and Mg (PETTER et al., 2012).

The results show that for plant height, the most appropriate time of $\mathrm{K}$ application was at sowing. However, for soybean cultivation, potassium fertilization can be applied both at sowing and topdressing (SILVA and LAZARINI, 2014).

Topdressing application of potassium at different times in the Cerrado of the State of Piauí did not affect the weight of one thousand grains, despite being one of the main yield components. Thus, no significant effect was detected for time, nor for $\mathrm{K}$ doses, as well as the length of pods and the number of pods in the upper and lower thirds (Table 3). 
Table 3. Summary of the analysis of variance for NVP: number of pods per plant; NGV: number of grains per pod. CV: pod length. NVTS: number of pods in the upper third; NVTM: number of pods in the middle third; NVTI: number of pods in the lower third: Prod.: Yield; PMG: one-thousand grain weight

\begin{tabular}{|c|c|c|c|c|c|c|c|c|c|}
\hline \multirow{2}{*}{$\begin{array}{l}\text { Source of } \\
\text { variation }\end{array}$} & \multirow{2}{*}{$\begin{array}{c}\text { Degrees } \\
\text { of } \\
\text { freedom }\end{array}$} & \multicolumn{8}{|c|}{ Mean square } \\
\hline & & NVP & NGV & $\mathrm{CV}$ & $\begin{array}{c}\text { NVT } \\
\text { S }\end{array}$ & NVTM & NVTI & PROD & PMG \\
\hline Dose (D) & 3 & 134.97 & 557.64 & 0.0040 & 1.95 & 0.1142 & 40.62 & 907.18 & 8.74 \\
\hline Time (E) & 3 & 20.23 & 573.83 & 0.0891 & 13.41 & 0.2712 & 9.46 & 43.48 & 18,11 \\
\hline D X E & 9 & 46.17 & 235.42 & 0.7677 & 6.57 & $0.058^{*}$ & 26.57 & $18.19 *$ & 18,65 \\
\hline Residual & 45 & 54.59 & 276.37 & 0.5812 & 7.24 & 0.227 & 19.69 & 78.6 & 15,58 \\
\hline \multicolumn{2}{|c|}{ C.V. $(\%)$} & 28.6 & 31.96 & 6.61 & 40.21 & 18.35 & 34.96 & 30.62 & 15.58 \\
\hline
\end{tabular}

* Significant by F-test $(\mathrm{P}<0.05)$.

There was interaction between dose and time of application for the number of pods in the middle third (Figure 3) and yield; in which NVTM is a direct indicator related to increased crop yield. The dose of $109 \mathrm{~kg} \mathrm{ha}^{-1} \mathrm{KCl}$ resulted in a higher number of grains in the middle third and the best time for application was at sowing. For yield, in general, the ideal dose was $105.67 \mathrm{~kg} \mathrm{ha}^{-1}$ (Figure 4).

In the V3 + R1 stage, the number of pods in the middle third was reduced, however it was not enough to decrease the yield. This is due to the potassium exploitation capacity in the soil, which even with the occurrence of water deficit during the experiment (Figure 1), was able to reduce its effects, presenting positive response to potassium fertilization with significant increase in yield. 

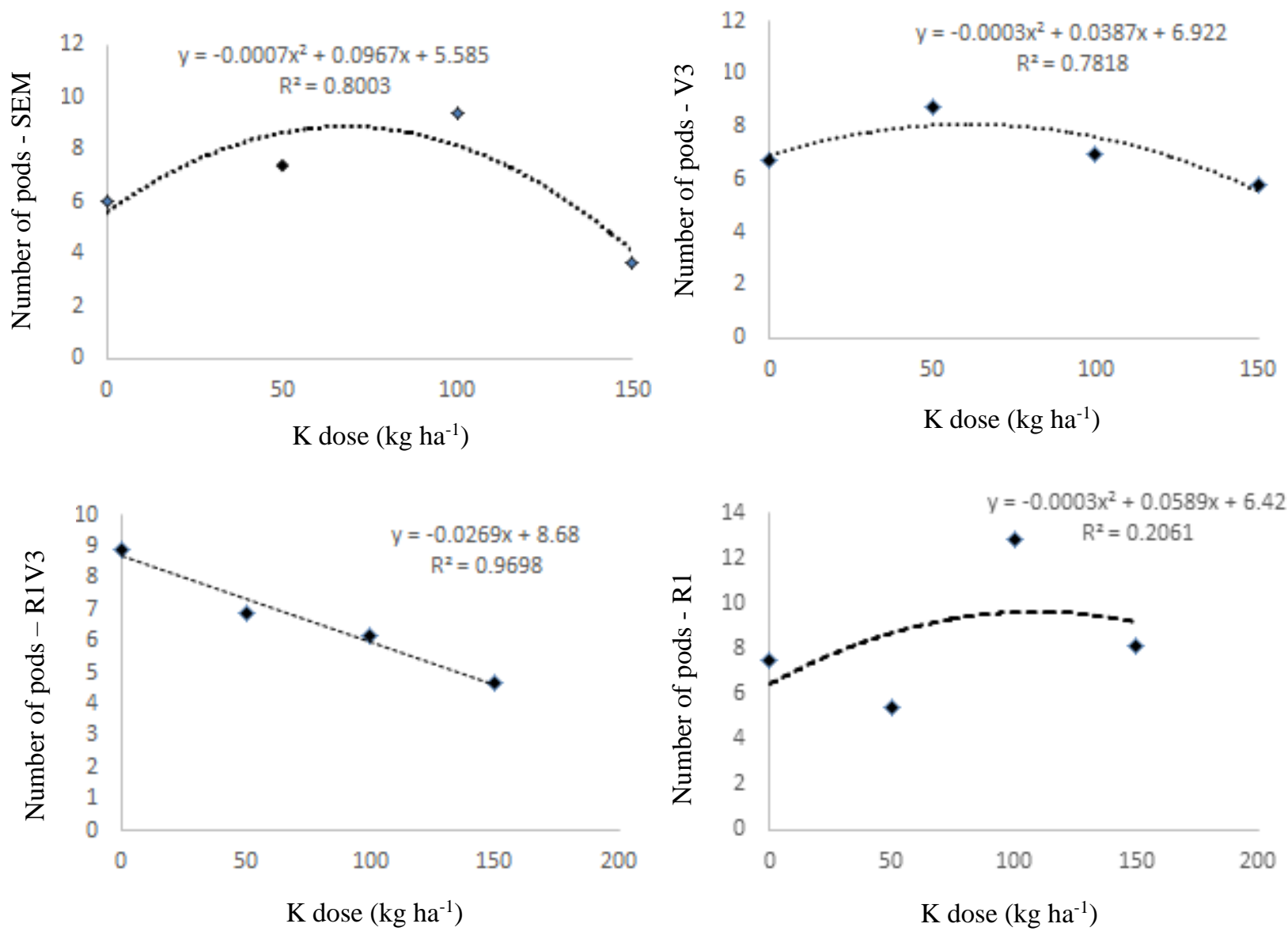

Figure 3. Number of pods in the middle third of the soybean plants

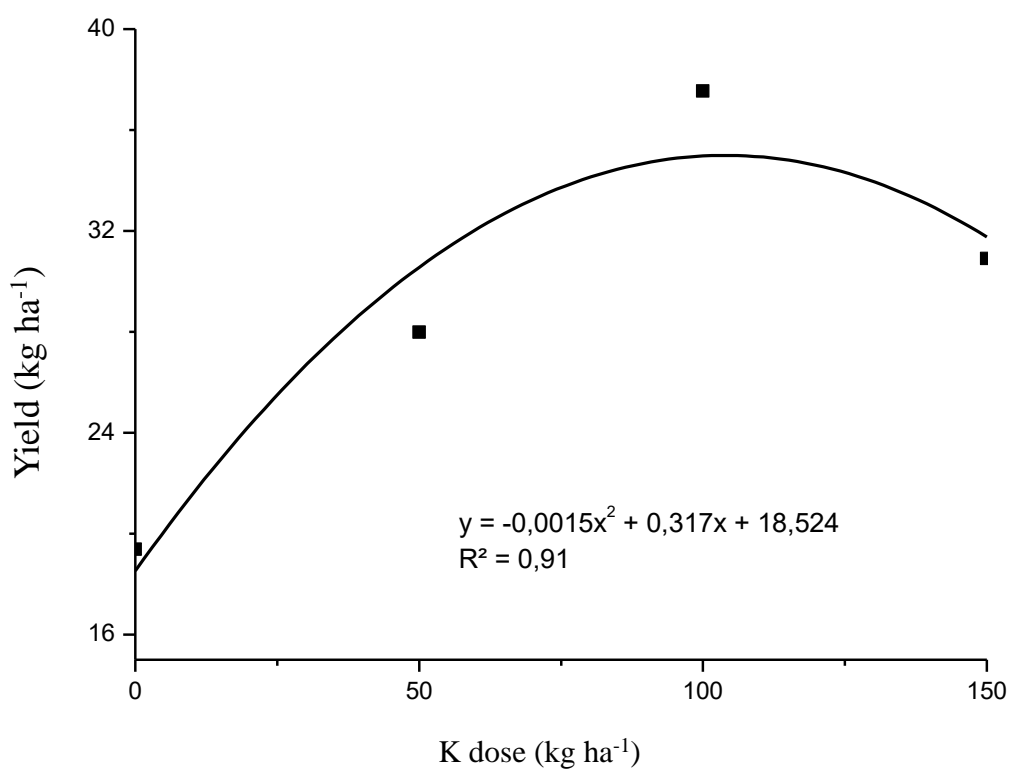

Figure 4. Soybean yield according to $\mathrm{K}$ doses 


\section{Macrothink}

Yield was influenced by $\mathrm{KCl}$ doses, but it was not related to the time of application of this nutrient. Potassium fertilization induced the response in soybean plants increasing yield (Figure 4). These results corroborate Foloni and Rosolem (2008), who verified higher soybean yields with applications of $90 \mathrm{~kg} \mathrm{ha}^{-1} \mathrm{~K}_{2} \mathrm{O}$. For Duarte et al. (2016), the number of seeds per plant and grain yield increase linearly with increasing fertilizer doses.

The increasing yield response can be attributed to the increase in production components and is related to the ways in which plants use $\mathrm{Km}$ as it can provide plants with the most efficient use of water and nutrients, so that plants become more tolerant to environmental stress (PETTIGREW, 2008). In addition, potassium fertilization directly interferes with crop yield, since $\mathrm{K}$ is related to protein synthesis, and its deficiency can lead to accumulation of free amino acid concentration in soybean plant tissue, and increase the susceptibility to pests and diseases (MYERS et al., 2005).

For better use of $\mathrm{K}$ by plants in Cerrado soils, it is still necessary to define the best time of application of this nutrient, due to the specific soil and climatic conditions of the region. Therefore, the choice of applying total $\mathrm{K}$ at sowing or according to the stages of crop development should be a function of the costs or optimization of application operations, as well as the greater economic efficiency in using $\mathrm{K}$, with reduced production costs according to fertilization management.

Given this, economic analysis was performed to evaluate the economic viability of the potassium doses tested. Considering the maximum economic efficiency (MEE), the dose that provides the maximum economic return for the applied fertilizer, taking into account the price of $\mathrm{KCl}$ and the soybean price, this means that applications above the dose to reach the MEE may provide higher yield, but with lower profit.

The regression results and the coefficient of determination are listed in Table 4. With the available equation, it was possible to calculate the production stages 2 and 3, to set the limits of rational use of potassium, as well as the optimal dose to reach the highest yield. 


\section{Macrothink Institute ${ }^{\mathrm{TM}}$}

Table 4. Summary of analysis of variance of regression, production equation parameters and coefficient of determination of the economic analysis

\section{Mean square}

DF $\quad$ SQ

\begin{tabular}{|c|c|c|c|}
\hline & \multicolumn{2}{|l|}{ DF } & SQ \\
\hline Explained & \multicolumn{2}{|l|}{3} & $1466163.617 * *$ \\
\hline Unexplained & \multicolumn{2}{|l|}{30017} & 2120677.057 \\
\hline $\mathrm{R}^{2}$ & \multicolumn{2}{|l|}{0.4088} & \\
\hline \multicolumn{4}{|c|}{ Regression } \\
\hline & & Coefficient & Standard error \\
\hline Constant & & $20.5464 * *$ & 0.0840 \\
\hline $\mathrm{Cx}$ & & $-1.6085^{* *}$ & 0.6906 \\
\hline $\mathrm{Bx}^{2}$ & & $12.5489 * *$ & 0.9594 \\
\hline$A x^{3}$ & & $-3.7404 * *$ & 0.3117 \\
\hline
\end{tabular}

$* *=$ significant at $0.1 \%$ probability.

Taking into account the soybean price of US $\$ 21.66$ per $60 \mathrm{~kg}$ bag and the $\mathrm{KCl}$ of US $\$ 476.19$ per ton for January 2017 , the application of $109.9 \mathrm{~kg} \mathrm{ha}^{-1} \mathrm{KCl}$ generates a profit of US \$ 309.39. While applying $112.56 \mathrm{~kg} \mathrm{KCl}$ per hectare, the profit is US \$ 308.77, thus it is observed that with increasing doses of $\mathrm{K}$ the net revenue tends to grow to a maximum, then begins to decrease. These results reinforce and corroborate Mitscherlich's law of diminishing returns, which states that as the dose of a given fertilizer increases, the yield response is reduced exponentially.

Yield reduction from $112.56 \mathrm{KCl} \mathrm{ha}^{-1}$ dose may be due to salt concentrations in $\mathrm{KCl}$, which hinders water absorption by seeds, and compromises root and vegetative development of plants due to external osmotic pressure (TAVARES, 2012). In studies with different doses of $\mathrm{KCl}$, Petter et al. (2012) verified the absence of the increasing effect on yield with applications above $90 \mathrm{~kg} \mathrm{ha}^{-1} \mathrm{~K}_{2} \mathrm{O}$, attributing the nutritional imbalance of $\mathrm{K}$ to $\mathrm{Ca}$ and $\mathrm{Mg}$.

The maximum dose of technical viability was $112.56 \mathrm{KCl} \mathrm{ha}^{-1}$, which generates a profit of US \$ 307.65 and the optimal dose of economic viability is $109.9 \mathrm{KCl} \mathrm{ha}^{-1}$ with a profit of US $\$ 308.27$, when compared to the zero dose of $\mathrm{KCl}$. The economic analysis of soybean cultivation showed a grain yield of $2295 \mathrm{~kg} \mathrm{ha}^{-1}$, obtained by applying $109.9 \mathrm{~kg} \mathrm{KCl} \mathrm{ha}{ }^{-1}$, 
while the control presented a yield of $1231.4 \mathrm{~kg} \mathrm{ha}^{-1}$, which accounted for around $86.5 \%$ more grain yield than the control. These results are related to the adequate supply of $\mathrm{K}$, since it increases the efficiency in the uptake and use of nutrients such as nitrogen, due to the development of a strong and healthy root system, thus providing higher yield with lower production costs (IPI, 2013).

\section{Conclusions}

Potassium fertilization had a positive effect on soybean yield and there was no direct relationship with the time of application.

The dose of $105.7 \mathrm{KCl}$ ha-1, under the conditions of this experiment, obtained the highest soybean yield.

The dose $109 \mathrm{KCl}$ ha-1 provided greater economic viability in soybean crop.

\section{References}

Barbosa, G. F., Centurion, M. A. P. C., \& Ferraudo, A. S. (2014). Potencial do manejo integrado da ferrugem asiática da soja: severidade da doença, desenvolvimento vegetativo e componentes da produção, cultivar MG/BR-46 (Conquista). Bioscience Journal. Uberlândia, $30(3)$, 76-89. Retrieved

from http://www.seer.ufu.br/index.php/biosciencejournal/article/view/15037

Bohn, N. P., Lustosa Filho, J. F., Nóbrega, J. C. A., Campos, A. R., Nóbrega, R. S. A., \& Pacheco, L. P. (2016). Identificação de cultivares de soja para a região sudoeste do Cerrado $\begin{array}{llll}\text { piauiense. } & \text { Revista } & \text { Agro@mbiente. } & 10(1),\end{array}$ https://doi.org/10.18227/1982-8470ragro.v10i1.2911

Borghi, E., Bortolon, L., Avanzi, J. C., Bortolon, E. S. O., Ummus, M. E., Gontijo Neto, M. M., \& Costa, R. V. da. (2014). Desafios das novas fronteiras agrícolas de produção de milho e sorgo no Brasil: desafios da região do MATOPIBA. In: Karam, D., Magalhães, P. C. (Ed.). Eficiência nas cadeias produtivas e o abastecimento global. Sete Lagoas: Associação Brasileira de Milho e Sorgo, cap. 25, 263-278.

Brasil. (2009). Ministério da Agricultura, Pecuária e Abastecimento. Regras para análise de sementes. Brasília: Mapa/ACS, 399 p.

Camargos, M. A., \& Coutinho, E. S. (2008). A teoria da firma e a fundamentação teórica para fusões e aquisições: uma análise de suas interfaces. RAC Eletrônica. 2(2), 273-295. http://www.spell.org.br/documentos/ver/31072/a-teoria-da-firma-e-a-fundamentacao-teoricapara-fusoes-e-aquisicoes--uma-analise-de-suas-interfaces/i/pt-br

Dalchiavon, F. C., \& Carvalho M. P. (2012). Correlação linear e espacial dos componentes de produção e produtividade da soja. Semina: Ciências Agrarias, Londrina, 33(2), 541-552. https://doi.org/10.5433/1679-0359.2012v33n2p541

Duarte, T. C., Cruz, S. C. S., Soares, G. F., Sena Júnior, D.G., \& Machado, C. G. (2016). Spatial arrangements and fertilizer doses on soybean yield and its components. Rev Bras 
https://doi.org/10.1590/1807-1929/agriambi.v20n11p960-964

Embrapa (2015). - Empresa Brasileira de Pesquisa Agropecuária. MATOPIBA GeoWeb. Disponível em: <http://goo.gl/bZSz8Y>. Acesso em: 31/05/2018.

Foloni, J. S. S., \& Rosolem, C. A. (2008). Produtividade e acúmulo de potássio na soja em função da antecipação da adubação potássica no sistema plantio direto. Rev Bras Ciênc Solo, 32(1), 1549-1561. https://doi.org/10.1590/S0100-06832008000400019

Gavioli, E. A. (2012). Explanations for the Rise of Soybean in Brazil. In: Board, J. E. A comprehensive survey of international soybean research - genetics, physiology, agronomy and nitrogen relationship. Croatia, Published by InTech Janeza Trdine 9, 51000 Rijeka. Cap. 16. https://doi.org/10.5772/45867

Hao, X., Li, P., Han, X., Norton, R. M., Lam, S. K., Zong, Y., ... Gao, Z. (2015). Effects of free-air $\mathrm{CO} 2$ enrichment (FACE) on $\mathrm{N}, \mathrm{P}$ and $\mathrm{K}$ uptake of soybean in northern China. Agricult Forest Meteorol, online. https://doi.org/10.1016/j.agrformet.2015.12.061

Ipi - International Potash Institute. (2013). Potássio, o Elemento da Qualidade na Produção Agrícola, online, 2013.

Martins, I. S., Cazetta, J. O., \& Fukuda, A. J. F. (2014). Condições, modos de aplicação e doses de ureia revestida por polímeros na cultura do milho. Pesq Agropec Trop, Goiânia, 44(3), 271-279. https://doi.org/10.1590/S1983-40632014000300010

Meenaa, V. S., Maurya, B. R., \& Verma. J. P. (2014). Does a rhizospheric microorganism enhance K+availability inagricultural soils?. Microbiological Research, 169(5), 337-347. https://doi.org/10.1016/j.micres.2013.09.003

Myers, S. W., Gratton, C., Wolkowski, R. P., \& Hogg, D. (2005). Effect of soil potassium availability on soybean aphid (Hemiptera: Aphididae) population dynamics and soybean yield. $\begin{array}{lllr}\text { Journal economic entomology, } & \text { Califórnia, } & 98(1), & 113-120 .\end{array}$ https://doi.org/10.1603/0022-0493-98.1.113

Oosterhuis, D. M., Loka, D. A., Kawakami, E. M., \& Pettigrew, W. T. (2014). The Physiology of Potassium in Crop Production. Advances in Agronomy, online. https://doi.org/10.1016/B978-0-12-800132-5.00003-1

Palisade. 2016. Disponível em: < www.palisade-br.com/risk/>. Acesso em: 15 abril 2017.

Pazzini, H. S., Murta, A. L. S., Motta, C. K., \& Stringari, D. (2014). Viabilidade econômica de Monte Carlo da produção de Biodiesel de resíduos de soja. Rev Bras Administ Científ, Aquidabã, 6(1). https://doi.org/10.6008/SPC2179-684X.2015.001.0005

Petter, F. A., Alves, A. U., Silva, J. A., Cardoso, E. A., Alixandre, T. F, Almeida, F. A, \& Pacheco, L. P. (2014). Produtividade e qualidade de sementes de soja em função de doses e épocas de aplicação de potássio. Semina: Ciências Agrárias, Londrina, 35(1), 89-100. https://doi.org/10.5433/1679-0359.2014v35n1p89 
Petter, F. A., Silva, J. A., Pacheco, L. P., Almeida, F. A., Alcântara Neto, F., Zuffo, A. Z., \& Lima, L. B. (2012). Desempenho agronômico da soja a doses e épocas de aplicação de potássio no cerrado piauiense. Revista de Ciências Agrárias, 55(3), 190-196. https://doi.org/10.4322/rca.2012.057

Pettigrew, W. T. (208). Potassium influences on yield and quality production for maize, wheat, kksoybean and cotton. Physiologia Plantarum, 133(4), 670-681. https://doi.org/10.1111/j.1399-3054.2008.01073.x

Pragana, R. B. (2011). Caracterização pedológica e diagnóstico da qualidade de solos sob plantio direto na Serra do Quilombo, sudoeste piauiense. 159 f. Tese (Programa de Pós-Graduação em Ciência do Solo) - Universidade Federal Rural de Pernambuco, Recife.

Pragana, R. B., Ribeiro, M. R., Nóbrega, J. C. A., Ribeiro Filho, M. R., \& Costa, J. A. (2012). Qualidade física de Latossolos Amarelos sob plantio direto na região do Cerrado piauiense. Rev Bras Ciênc Solo, 36(5), 1591-1600. https://doi.org/10.1590/S0100-06832012000500023

Richetti, A. (2015). Viabilidade econômica da cultura da soja na safra 2015/2016, em Mato Grosso do Sul. Comunicado Técnico, Dourados - MS, 2015. https://www.infoteca.cnptia.embrapa.br/infoteca/bitstream/doc/1021354/1/COT20152021.pdf

Sales, V. H. G., Peluzio, J. M., Afférri, F. S., Oliveira-Junior, W. P., \& Sales, P. V. G. (2016). Teor de óleo e proteína em grãos de soja em diferentes posições da planta. Revista Agro@mbiente, 10(1), 22-29. https://doi.org/10.18227/1982-8470ragro.v10i1.2462

Schmid, L., Silva, C. M., Medeiros, J. C., \& Mielezrski, F. (2016). Influence of delayed nitrogen on production and physiological potential of soybean seeds. Seed Technology, 37(1), 175-183. https://stjournal.org/volume-37-no-2-2016/.

Serafim, M. E., Ono, F. B., Zeviani, W. M., Novelino, J. O., \& Silva, J. V. (2012). Umidade do solo e doses de potássio na cultura da soja. Rev Ciênc Agronôm, 43(2), 222-227. https://doi.org/10.1590/S1806-66902012000200003

Silva, A. F., \& Lazarini, E. (2014). Doses and application seasons of potassium on soybean crop in succession the cover crops. Semina: Ciências Agrárias, Londrina, 35(1), 179-19. https://doi.org/10.5433/1679-0359.2014v35n1p179

Souza, C. A., Figueiredo, B. P., Coelho, C. M. M., Casa, R. T, \& Sangoi, L. (2013). Arquitetura de planta e produtividade da soja decorrente do uso de redutores de crescimento. Bioscience Journal. 29(3),

http://www.seer.ufu.br/index.php/biosciencejournal/article/view/141

Srinivasarao, C. H., Shanker, A. K., Kundu, S., \& Reddy, S. (2016). Chlorophyll fluorescence induction kinetics and yield responses in rainfed crops with variable potassium nutrition in $\mathrm{K}$ deficient semi-arid alfisols. Journ Photochem Photobiol, B: Biology, 60(1), 86-95. https://doi.org/10.1016/j.jphotobiol.2016.03.052

Taiz, L., \& Zeiger, E. (2013). Fisiologia vegetal. 5.ed. Porto Alegre:Artemed, 954p. 


\section{Macrothink}

Journal of Agricultural Studies

ISSN 2166-0379 2020, Vol. 8, No. 3

Tavares, L. C., Tunes, L. M., Brunes, A. P., Fonseca, D. A. R., Rufino, C. A., \& Barros, A. C. S. A. (2013). Potassium via coating of soybean seeds: effects on physiological quality and yield. Ciência Rural, Santa Maria, 43(7), 1196-1202. https://doi.org/10.1590/S0103-84782013000700009

Wang, X., Zhao X., Jiang C., Li C., Cong S., Wu D., Chen Y., Yu H., \& Wang C. (2015). Effects of potassium deficiency on photosynthesis and photoprotection mechanisms in soybean (Glycine $\max$ (L.) Merr.). Journ Integrat Agricult, 14(5), 856-863. https://doi.org/10.1016/S2095-3119(14)60848-0

Zörba, C., Senbayramb, M., \& Peiter, E. (2014). Potassium in agriculture - Status and perspectives. Journal of Plant Physiology, 171(9), 656-669. https://doi.org/10.1016/j.jplph.2013.08.008

\section{Copyright Disclaimer}

Copyright for this article is retained by the author(s), with first publication rights granted to the journal.

This is an open-access article distributed under the terms and conditions of the Creative Commons Attribution license (http://creativecommons.org/licenses/by/4.0/). 